\title{
Successful Instructional Reading Practices for African American Male Third-Grade Students
}

\author{
Kimberly D. Whaley \\ Walden University \\ Steve Wells \\ Walden University \\ Nancy Williams \\ Walden University
}

\begin{abstract}
African American male third graders in U.S Title I schools frequently fail to read on grade level. However, in three Title I schools in East Texas, this demographic demonstrated exceptionally high reading ability. This explanatory case study investigated the instructional strategies and practices linked to high reading achievement for these students. The study is grounded in Ladson-Billings's theory of culturally relevant pedagogy and supported by Vygotsky's theory of social and cognitive constructivism. The research questions were used to examine the instructional strategies and practices used on each campus that may have resulted in such high reading achievement. This study engenders a deeper understanding of effective instructional reading strategies and practices for African American boys at the elementary level.
\end{abstract}

Keywords: instructional, reading, practices, African American, boys, CRP, culturally relevant pedagogy

\section{Introduction}

Most third-grade Title I African American boys in the United States require some form of intervention to succeed in the reading classroom (Davis, 2016; Meier, 2015; Webb \& Thomas, 2015; J. Williams \& Portman, 2014; V. Williams, 2015). Reading achievement appears to be hindered by low expectations from teachers (E. Williams, 2015), intergroup bias (Bigler \& Wright, 2014), and stereotyping (Wasserberg, 2014). Corresponding to national trends, Texas reading performance of African American boys is also substandard according to state assessment reading scores (Texas Education Agency, n.d.) Amid this bad news, however, there are a few bright spots. In East Texas, three Title I elementary schools clearly exceeded the reading achievement norms for third-grade African American boys (Texas Education Agency, n.d.). The current study improved understanding of just how this success was accomplished. Such inquiry generates pedagogical knowledge that supports reading education (Dumas, 2017; J. Williams \& Portman, 2014) and provides insight into best reading practices (Snow \& Matthews, 2016). According to Newman-Brown (2016), studies related to academic success have been limited; plus, few successful instructional strategies have been scrutinized through research for this population (Rowley et al., 2016). 


\section{Problem Statement}

The research problem this study addressed was insufficient understanding of instructional practices linked to the high reading achievement of third-grade African American boys in Title I schools in East Texas. Research (Tomkinson, 2016; E. Williams, 2015; J. Williams \& Portman, 2014, V. Williams, 2015) has indicated a need for increased understanding of effective instructional practices for the focus population. More specifically, understanding is needed about successful strategies that support positive academic experiences for African American boys (Rowley et al., 2016).

\section{Gap in the Literature}

Not understanding how they did it—-that is, how the educators in the Title I school delivered such high reading achievement in third-grade African American boys-is a current and meaningful problem in the educational discipline. Newman-Brown (2016) held that input from teachers who successfully instructed the children was needed to address a gap in the research literature.

Investigation into instructional strategies that supports the students' success is necessary to address those practices that might impede the success of the learners (Liou \& Rotheram-Fuller, 2019). J. Williams and Portman (2014) reported that there is a need to learn more about instructional strategies that support the academic achievement of at-risk African American boys. Rowley et al. (2016) also stressed the necessity of further research to develop effective instructional methods to meet the needs of African American boys. Tomkinson (2016) urged additional research to include teacher perspectives of effective reading instruction for African American boys. She observed that few teachers have been interviewed about best instructional practices for reading with this population. This study constituted a next logical step in the inquiry called for in the aforementioned studies.

\section{Purpose}

The purpose of this explanatory case study was to investigate the instructional practices, or how the campuses applied their instructional strategies, at these three East Texas Title I schools pertaining to effective reading instruction for third-grade African American boys. Through this study, we sought explanations as to how the instructional practices in these successful schools are linked to high levels of reading achievement (see Gray, 2017). The study provided a precise description of the case facts, consideration of alternate causes, and an evidence-based conclusion (see Yin, 2013b).

The findings can benefit teachers and students academically. Professional development can be guided by the findings of the research focused on improvement of instructional practices, increasing teacher knowledge of effective instructional strategies. The culmination of these actions can then lead to enhanced learning opportunities for the population in the area of reading, potentially providing insight that could lead to a higher level of learning for students. With a newfound level of learning, the lifelong opportunities for these students could increase due to the students' academic success (Kirsch \& Lennon, 2017).

\section{Culturally Relevant Instruction}

Davis (2016) explained that it is necessary to choose correct materials and pedagogical approaches for diverse populations. It is important for teachers, and those in the education field, to implement a path to instruction that will support a culturally relevant pedagogical approach providing support to this population of students. Individual needs should dictate the instructional approach teachers take to instruct their students (Snow \& Matthews, 2016). Paris and Alim (2014) and Kelly (2013) found that students' cultures should be supported linguistically, literacy-wise, and pedagogically. LadsonBillings's (1995a) theory of culturally relevant pedagogy (CRP) holds that a culturally relevant 
approach is necessary for academic success, cultural competence, and development of critical consciousness for both students and educators (p. 160). Therefore, students' needs should guide instruction through culturally significant approaches appropriate to attain the level of success each student deserves.

\section{Research Questions}

Research Question 1: What strategies and/or methods are third-grade instructional staff using to present reading instruction to third-grade African American boys enrolled in three high-performing Title I schools in East Texas?

Research Question 2: What supports do campus-level administrators and teachers report are being used to guide effective reading instruction for third-grade African American boys enrolled in three high-performing Title I schools in East Texas?

Research Question 3: How are instructional practices, in the research schools, perceived to explain, or not explain, the high levels of reading achievement of third-grade African American boys enrolled in three high-performing Title I schools in East Texas?

\section{Literature Review}

The literature review emphasizes the key concepts of CRP in the elementary classroom linked to reading instruction for African American boys. Throughout the literature review, themes were evident in all areas of research. These areas included the specifics of CRP, academic success, cultural competence, and development of critical consciousness, supported by constructivism. Specifically, the research showed that the integration of CRP was beneficial to all stakeholders.

\section{Conceptual Framework}

The conceptual framework for this study was composed of Ladson-Billings's (1995a) theory of CRP, a theory supported by Vygotsky's (2004) theory of cognitive and social constructivism. CRP connects emphasis on academic success, cultural competence, and development of critical consciousness to the learning process of students (Ladson-Billings, 1995a). It consists of pedagogical practices that are implemented for students to succeed academically. CRP provides a foundation to understand factors that must be considered when designing effective reading instruction to meet the unique needs of African American boys.

Constructivism is the foundation for Ladson-Billings's theory of CRP. According to CRP, students construct their own meaning through various approaches within the parameters of learning. Fraise and Brooks (2015) confirmed that CRP is a constructivist view in which teachers and students learn as they construct knowledge together. According to Au (1998), implementation of a constructivist approach has a positive influence on literacy skills of minority students when implemented through CRP (Jones \& Brader-Araje, 2002). Specifically, both constructivism and CRP indicate learners must make meaning from personal experiences in order for real learning to occur.

Vygotsky had strong beliefs concerning the importance of culture in the classroom. He explained that children understand each phenomenon differently based on their own perspectives and experiences. "Vygotsky extended the emphasis on culture and society in his argument that all higher mental functions are social in origin and are embedded in the context of the sociocultural setting" (Jones \& Brader-Araje, 2002, p. 5). Vygotsky believed a student's culture defined who they were, and that the social component of learning requires students to understand each other. To do this, the students must have a clear understanding of each other's cultures. A teacher would be remiss to overlook students' cultures when developing learning opportunities (Powell \& Kalina, 2009). CRP aligns with 
these beliefs (Ladson-Billings, 2014). Understanding constructivist beliefs concerning the need for culture in the classroom and Ladson-Billings's views on the aspects of learning provides insight to the close intertwining of the two theories and their relevance to our study.

\section{CRP and the African American Male Student}

Implementation of culturally relevant approaches makes a difference for even the youngest student (Durden, Escalante, \& Blitch, 2015). For students to be taught effectively, teachers must demonstrate cultural awareness (Ford, Stuart, \& Vakil, 2014). This includes reading fiction and nonfiction pieces of literature that align with the diverse group's background. Bulletin boards and activities should be designed and aligned with the students' cultures (Ford et al., 2014). Anything may be considered if it makes a connection with the students while recognizing their culture is powerful (Kelly, 2013; Webb \& Thomas, 2015).

Educational literature about African American male students is replete with references to relationships. Of great importance are relationships between the student and the teacher (FriesBritt, 2017). Teachers having strong relationships with students can guide students to positive academic outcome (Allen \& White-Smith, 2014; Gay, 2013). Relationships allow individuals to build their own personal knowledge of their environment and experiences (Powell \& Kalina, 2009). We considered the importance of student-teacher relationships during interviews, classroom observations, and data analysis.

\section{Instruction}

With the Common Core curriculum in place in most of the United States, teachers find there is an overwhelming amount of material to teach. According to Duggins and Acosta (2019), teachers have very little control over their choice of literature due to curriculum constraints. By following the prescribed plan and material choices, teachers are often required to teach every child and every class the same. This practice does not allow for differentiation for the specific needs of the students. Although, over time, there have been numerous points made about the lack of achievement by the African American population in reading, the curriculum choices and practices that are often chosen do not address the needs of these students (Edwards \& Taub, 2016). Without the opportunity for teachers to determine the specific needs of their students, it is difficult to expect all children to succeed (Duggins \& Acosta, 2019). These diverse students need explicit, individualized instruction (Cartledge, Keesey, Bennett, Ramnath, \& Council, 2016).

\section{Method}

Research was conducted through a qualitative explanatory case study. Because the investigation was designed to study a need of a certain population, in this case, the third-grade African American male population in Title I schools, an explanatory case study approach was appropriate for a study of this nature (see Jenkins, 2016; Ravitch \& Carl, 2016). This study was based on real-life occurrences, another characteristic of an explanatory case study (see Yin, 2013a). An explanatory case study is an apt approach to determine the how and why of a condition when the researcher does not have any influence over the case (Taylor \& Thomas-Gregory, 2015). Had this been a situation where outcomes were indeterminate, an exploratory case study may have been more appropriate (see Butin, 2010). However, because there were clear outcomes, this study merited an explanatory case study. In addition, we focused on the how and why of the phenomenon of reading instruction for this population (see Yin, 2013a). Taylor and Thomas-Gregory (2015) noted case studies are well-suited for a how and why inquiry when the researcher does not have much, if any, jurisdiction over the circumstances. Through this case study, specific explanations focused on how instruction was transmitted and the purpose of the approach in the three Title I elementary schools was presented 
across the collected data. Through the findings of this study, we sought to explain how instructional approaches connected to the successful reading performance of the African American male population in third grade.

\section{Role of the Researcher}

Classroom observations and semistructured interviews were conducted with teachers and administrators who were involved with the reading instructional practices on the campuses of the target population (see Ravitch \& Carl, 2016). We had no personal or professional relationships with any of the campuses on which research was conducted. Ethically, the researcher must be aware of inherent bias and consider each step taken to avoid bias as much as possible (Ravitch \& Carl, 2016). We avoided inserting personal beliefs into the investigation and followed the research plan judiciously. Through specific attention to the detail of the research plan, we minimized the influence of bias within the study.

\section{Participant Selection}

Three schools located in the two largest counties in East Texas were identified based on the percentage of tests passed by the study's target population (see Texas Education Agency, n.d.). These three schools' scores were significantly higher than any other Title I schools in the area. The districts in which the schools were located were three of the largest school districts in the region. The research site in each district was the only school that attained such high scores in reading for this population.

We employed purposeful sampling to choose staff members of the research schools based on their knowledge of the studied phenomenon (see Ravitch \& Carl, 2016). Purposeful sampling, also known as judgmental sampling, allows participants to be chosen based on the researcher's judgment aligned to the study's purpose (Babbie, 2017). Each participant was chosen due to his or her intimate involvement in planning and providing instruction to the target population. Although the teachers' level of experience and ethnicity are noted in general, neither of these characteristics was a criterion for selection within this study. Participants on each campus included the campus administrator and two third-grade reading teachers. Of the four administrators included in the study, three were African American women, and one was a White woman. The administrators had been employed as educators for 10 to 33 years, with experience as a campus administrator ranging from 3 days to 8 years. Of the six teachers included in the study, two were African American women, and four were White women. The teachers had been employed as educators for 6 to 22 years, with experience as a third-grade reading teacher on these campuses ranging from 1 to 11 years.

\section{Data Collection}

Face-to-face semistructured interviews were conducted with one administrator and two third-grade reading teachers on each identified campus. The semistructured interview protocol was developed based on Ladson-Billings's (1995a) theory of CRP and the three research questions for the study. These questions were developed to possess interpretive, as well as theoretical, validity (see Ravitch \& Carl, 2016, pp. 190-191). Through these questions, meaning was determined from the interviewees' responses, providing an opportunity to explain the phenomenon investigated within the study. Interviews lasted 30-60 min. Notes were taken by hand and typed within a wordprocessing program. 


\section{Personal Reflection}

Each classroom teacher had the opportunity to complete a short personal inventory to reflect on his or her instructional environment in the area of reading with third-grade African American boys. Teachers rated their instruction as absolutely, in progress, and not yet based on whether or not they felt it was culturally responsive. This personal inventory was based on Ladson-Billings's (1995a) theory of CRP. Each short reflective survey was completed by the classroom teacher by hand and returned.

\section{Classroom Observations}

Observations are common in qualitative research (Merriam \& Tisdell, 2015). Classroom observations of a reading lesson occurred in two third-grade reading classrooms on each campus. Observations allowed activities to be view in a natural setting (see Ravitch \& Carl, 2016). The observations occurred in the third-grade reading teachers' classrooms. The observations were scripted during the time in the classrooms. A published observation guide was adapted to organize the scripted notes. This field note guide aligned with Ladson-Billings's theory of CRP (1995a) proving its validity as a field notes guide to support the classroom observation process for implementation of CRP in the observed teachers' classrooms while teaching reading. The classroom observations were completed during a reading class in the teachers' classrooms. The observations lasted 1-3 hr due to different schedules and availability of the teacher participants.

\section{Field Notes}

Field notes are important to qualitative research and improve the depth of qualitative findings. Implementing observational field notes allows flexibility and exploration in a natural setting (Phillippi \& Lauderdale, 2018). Insight can be gained through the completion of reflective field notes (Ravitch \& Carl, 2016). Field notes were created immediately following the observation from the scripted notes. No conversations concerning the observation occurred until field notes had been recorded. The goal of the use of field notes was to present data that allowed the reader to feel they were present in the observation (see Merriam \& Tisdell, 2015). There were no variations in the data collection from the planned approach, save one classroom observation change due to the teacher's reassignment.

\section{Data Analysis Plan}

According to Babbie (2017), qualitative analysis is "the nonnumerical examination and interpretation of observations, for the purpose of discovering underlying meanings and patterns of relationships" (p. 391). With this in mind, a priori coding was used followed by open coding of all data collected. Axial coding finalized the coding process. At this point in the coding, categories were developed to focus on themes and advance the research study's findings (see Ravitch \& Carl, 2016; Rubin \& Rubin, 2012).

\section{Discrepant Cases}

When a discrepant case occurred in this study, the findings were considered to determine the cause of the outlier data. These data allowed me to understand the unique needs of a specific campus or student group. An important part of research is to define findings that will challenge the overall conclusions of the study (Ravitch \& Carl, 2016). Discrepant cases add to a well-rounded and thorough report and are received with interest and intrigue to add to the overall findings of the study.

\section{Trustworthiness}

Triangulation was used to improve the trustworthiness of the findings. Triangulation was evident through the use of individual interviews, reflective inventories, observations, and analysis of district data. From these data, complete picture of the findings emerged. Transferability was accomplished 
through the inclusion of three separate school campuses in three separate school districts in East Texas. A great amount of information was gathered that provided deep insight into the practices used on the three campuses. This led to a high level of trustworthiness in this research study (see Babbie, 2017; Ravitch \& Carl, 2016).

\section{Findings}

The results of the qualitative analysis indicated that the phenomenon of successful instruction can be explained, in part, by its alignment to the constructs of the conceptual framework of this study. Ladson-Billings's theory of CRP clearly aligned with the approaches and practices used on each of the research campuses (see Ladson-Billings, 1995b). In addition, Vygotsky's theory of social and cognitive constructivism supported the teachers' implementation of CRP on each campus (see Vygotsky, 2004). On each campus, educators strove to be culturally aware and provide opportunities for academic success for all students. This is the foundation of the theory of CRP (see LadsonBillings, 1995a).

There were three strong themes evident throughout the study. The strongest theme observed in each aspect of data collection, with every participant, was the need for strong relationships. The next theme presented in the data collected spotlighted the need for educator collaboration. Finally, the data showed that high expectations are necessary for third-grade African American boys to succeed in reading.

\section{Relationships}

Relationships must be formed with students, as well as their parents, in order for these students to experience academic success in reading. One of the participating educators not only worked with African American boys but is the mother of two African American boys. When asked what she most wanted me to know, she said, "It is so crucial that you build that relationship. You must have an understanding of those kids." She went on to share the necessity of finding connections that these students can relate to. To find these connections, the educator should consider activities that provide the opportunity to get to know and understand the student better. Something as simple as eating lunch and visiting with the student could provide this opportunity. The educator ended her explanation of the need for relationships with this comment: "The relationship is the most crucial key to getting the student to success." Palincsar (1998) pointed out the importance of building relationships and how these strong relationships lead to higher levels of academic success. Relationships are a positive approach to facilitating academic skills that lead to stronger reading skills.

\section{Collaboration}

The second theme evident throughout the data was the need for collaboration among the campus educators. The campus personnel presented strong collaboration in the form of teams, or professional learning communities (PLCs). In these PLCs, the educators evaluated student academic data to determine appropriate direction for instruction and specific instructional strategies to implement. Campus administrators participated in this collaboration process and supported the teachers as they developed individualized interventions for students. Most campuses followed the DuFour model of PLCs to determine what needed to be accomplished for each student based on their level of mastery (see DuFour \& DuFour, 2012). One administrator supported the use of PLCs to develop strong collaboration skills for the good of students by noting that within the PLC, she, along with her teachers, used the data to determine weaknesses that needed to be addressed, but they also looked at areas of strength to determine how that student could move to a higher level of rigor. She said, "We're looking at [those] data, and we're pulling and seeing the deficiencies with our students." The 
positive outcome of PLCs related to the implementation of CRP was confirmed in a study conducted by Benegas (2014). Collaboration in a PLC setting provides a nonthreatening environment where educators can discuss CRP based instructional strategies to address the needs of their students. Using a team mindset to determine best approaches to appropriate academic strategies is a positive tactic to address the needs of this group of students (see Edwards \& Taub, 2016; Kurtz-Costes, Swinton, \& Skinner, 2014).

\section{High Expectations}

The last theme evident from the collected data was setting high expectations for students as well as educators. Students often meet the expectations set before them (Wright \& Ford, 2016), and educators do the same. One administrator shared the importance of holding teachers, as well as herself, to high expectations. Because she felt the overall goal was to provide a successful educational experience for the students, everyone must be held to high expectations to meet that goal.

The educators in this study were clear that they had experienced positive results from setting high expectations for the African American male students in their classrooms. One teacher was transparent when she stated, "We don't show apathy. We let them know that they will, and they can, rise above this [referring to the external factors that might affect their emotions]." This group of students received high levels of emotional support from their teachers and administrators even though teachers did not allow students to make excuses. Through perseverance and great levels of support, the boys were able to succeed at a very high level because these educators took an approach that would not allow any problem to be too big.

\section{Discussion}

This study was based on the three research questions posed previously. The key findings from the study aligned with the study's conceptual framework. Through data collection and analysis, we found that the most important strategy, or plan, implemented by the three successful campuses was the aspect of building relationships with each student. According to the data, without this relationship, learning will not occur. When the relationship is in place, the study's focus population members desire to work with, and for, the teacher. In addition to the necessity of building relationships, there were other strategies that were effectively implemented (see Appendix).

\section{Research Question 1}

Research Question 1 focused on strategies and methods implemented to teach reading to African American boys in third grade on three Title I campuses in East Texas. Although each campus used different materials to teach the state-mandated reading curriculum, the data were similar on each campus. This information can benefit teachers as they plan appropriate reading instruction for similar populations. In turn, members of the study's focus population can benefit through more effective reading instruction leading to greater academic achievement.

All participants stressed the importance of using data to determine the individual needs of the students (see Edwards \& Taub, 2016). These needs were addressed by the teachers through individual direct instruction (see Snow \& Matthews, 2016). Within this instruction, teachers incorporated student choice. Ladson-Billings (2018) found that students should have the opportunity to choose within the learning process. The study's participants shared this same opinion when interviewed.

According to the study's participants, teachers must design learning activities that engage each learner. This mindset was affirmed by Coggshall, Osher, and Colombi (2013) in research that 
confirmed the importance of finding connections that engage students. The need for engaging activities was found to be true specifically in the area of reading (see Cartledge et al., 2016). CRP provides a way to connect the student to learning opportunities leading to higher levels of engagement (Ladson-Billings, 2018).

One very supportive style of instruction agreed upon by the study participants for the study's focus population was small group instruction. The researched literature concurred with this finding. Interventions must be tailored to individual students (Cartledge et al., 2016). Other researchers found that there was a need for the type of instruction presented in small group settings. These researchers extended the findings to include academics and culture within these small groups for students to reach their full academic capacity (Kurtz-Costes et al., 2014; Wiggan \& Watson, 2016).

\section{Research Question 2}

Research Question 2 focused on supports provided to teachers by campus administration. The amount of support may make a difference in the instructional strategies and practices implemented by classroom teachers. Likewise, the type of supports may affect the effectiveness of the instructional strategies. Education is a team effort. All members play an important role.

Collaboration was a theme throughout the collected data. This included collaboration of teachers with campus administrators and fellow teachers. This collaboration was facilitated through PLCs, planning sessions, and other modes of communication. It was within these collaborative periods that individualized strategies were developed and plans for implementation were made. This approach is beneficial to students' academic growth as well as educators' professional growth (Ladson-Billings, 2014).

Within the collaboration, data mining was used by the educators. Data mining is the act of breaking down data to determine specific needs (Ratner, 2017). Throughout the review of literature, the need for interventions and instruction to be differentiated and individualized for each student's needs was mentioned on numerous occasions (Cartledge et al., 2016). Evaluating data provides an opportunity for educators to observe achievement gaps between groups of students and evaluate specific instructional needs (Kurtz-Costes et al., 2014).

Each campus administrator was open to providing professional development individually or as a group for any teacher as needed. The administrators noted that the needs were based on academic data, classroom observations, and specific requests. Wright, Counsell, and Tate (2015) noted that teachers should be trained in CRP practices. One of the administrators specifically noted that the teachers on her campus had received this type of training, and it made a huge difference in how the African American male students responded and achieved, not only in reading but in all subjects. The majority of teachers shared that they received professional development support through their district, on campus, and off campus. This was confirmed by the campus administrators.

Materials are needed in the classroom to support learning. The majority of participants noted that this was a priority for everyone. Each administrator was open to obtain any requested materials. The common thread through the data was that the teachers need only explain the why behind the request. If there was evidence that the material would make a difference for student learning, it was procured for the teacher with the expectation of strong outcomes.

Within the literature, a strong need for culturally relevant materials was evident (Ladson-Billings, 1995a). However, within the study's data collection, culturally relevant bulletin boards, specific activities, nor literature intentionally aligned with one cultural group were observed. Ford et al. (2014) noted this practice should be followed for successful learning to occur. Furthermore, the literature revealed that researchers have stated that successful classrooms were rich in culturally 
relevant material such as literature, displays, and learning centers (Durden et al., 2015). These practices were not observed during the classroom observations nor were these practices mentioned as a successful approach by any participant in their interview or survey. Although all administrators were willing to attain any desired materials, the literature review research focused on the need for culturally relevant materials. This study indicated that attention to culturally relevant material was not as compelling. Therefore, the study's data disconfirmed the research from the literature review.

Many times, teachers are harnessed by the expectations of the school district or campus administrators. This may not be the best instructional approach for African American boys. A theme that was evident throughout the data analysis was that the campus administrators believed that teachers should be given the freedom and flexibility to teach the students in a manner that best suited their needs to reach high academic achievement.

Teachers should teach what students need. It is not necessary to follow a dictated curriculum (Duggins \& Acosta, 2019). The students' individual needs should dictate the instructional route (Snow \& Matthews, 2016). This differentiation was allowed on all campuses involved in the study. The teachers were allowed to do whatever it took to make certain that each child achieved mastery of the reading standards.

\section{Research Question 3}

Research Question 3 focused on those instructional practices the study participants found to be most influential for reading success in the African American male population. These practices narrowed to relationships, content knowledge, accountability for educators, and differentiation. Each of these points has potential to make a difference for the focus group.

By far, relationships were the greatest focus of all aspects of data collection in the study. Every participant spoke of the necessity for strong relationships to be built with African American male students when facilitating high academic achievement. Without relationships, learning will not occur (Gay, 2013). Furthermore, teachers must respect a student's uniqueness (Boon \& Lewthwaite, 2015). Relationships are especially important for African American students of poverty (Gay, 2013). Understanding the great influence a teacher has on a student proves building positive relationships is fundamental to academic success (Allen \& White-Smith, 2014).

Several teachers referred to themselves as connectors. Kelly (2013) noted the importance of connecting with, and validating, the student. This aligned with Drevdahl's (2016) and Wiggan and Watson's (2016) beliefs that for successful learning to occur with African American boys, their culture must be validated. Therefore, their culture must be acknowledged and integrated into instructional planning (Fraise \& Brook, 2015). The acceptance and embracement of culture allows relationships to develop, and grow, leading to greater opportunities for learning to occur (Coggshall et al., 2013; Palincsar, 1998). As noted by all participants, there is a connection between strong relationships and high levels of learning with the greatest association being the teacher (see Allen \& White-Smith, 2014). Teachers should understand the potential they have for not only academic support but personal support as well (Fries-Britt, 2017).

Research indicated that African American male mentors were a positive experience for African American male students (Wright et al., 2015). From the data collected and analyzed within this study, that finding is not always the case. According to the study's participants, African American male mentors are not always the best choice for African American male students. This conclusion is dependent on the student's life experience. A mentor is a positive influence. The mentor can be a member of the school faculty or staff or a community member. However, it is necessary to find an individual who best connects with a particular student. There are African American male students who have had experiences with African American boys that have not been positive. This was the case 
with one student observed during a classroom observation. This student required a White woman as his mentor. This was the one person this student connected with. Therefore, this was the best individual to fill the role of mentor for this student. With this mentor, the student had made great strides over the previous school year and continued to improve academically and socially. One size does not fit all when choosing a mentor for a student. Therefore, in the case of the research presented from the literature review that noted the positive influence of African American male mentors on African American male students, this study disconfirmed that research.

The data analysis indicated the need for a strong understanding of the content and standards by the teacher. Because there are so many extraneous nuances to reaching the African American male student that must be implemented through teaching strategies, a strong understanding of the content, as well as the required academic standards, is a must for all educators. Ladson-Billings addressed this finding in her research on CRP. Educators must have a thorough understanding of the standards to facilitate a high level of student achievement (Ladson-Billings, 1995a). The study's data confirmed the research presented in the review of literature.

Many researchers alluded to the need for accountability for teachers and administrators. After analyzing the study's data, this accountability is not only for one grade level or only the tested grade levels. All teachers must be held accountable for student learning. One grade level team cannot be responsible for all student learning. Each teacher builds upon the previous year of teaching and must work with the previous grade level teachers for successful student achievement. The other grade level teachers must be aware of the same needs the third-grade teacher must be aware of. They must hold themselves to the same level of accountability and meet the needs of each individual student. This data extends the knowledge previously reported in the literature review.

Teachers must differentiate, or individualize, their approach for each student (Cartledge et al., 2016). Every student has different needs. It is the teachers' and administrators' roles to adjust for this and support a student as he/she reaches academic success (Cartledge et al., 2016). Kurtz-Costes et al. (2014) focused their research on the need for customized instruction for African American boys. These researchers found that instruction should be personalized for both academics and culture.

Students must experience success. This can be accomplished through differentiation. When students experience success, they are driven to strive for more success (Ladson-Billings, 1995a). High expectations must be set for students. Boys tend to live out the expectations set for them (Wright \& Ford, 2016). With that in mind, all students should be treated as individuals with individual needs. Through this approach, students have a greater chance at success.

\section{Conceptual Framework}

The study's findings, overall, confirm Ladson-Billings's theory of CRP supported by Vygotsky's theory of social and cognitive constructivism (see Ladson-Billings, 1995a; Vygotsky, 1980). The data from the study confirmed the strong link between CRP and academically successful African American boys because each teacher participant on each of the campuses implemented some level of CRP with their students (see Ladson-Billings, 1995a).

According to the study's participants, meaning is made from personal experiences. The students then took the varied experiences presented to them in the classroom and built upon them to construct knowledge (see Jones \& Brader-Araje, 2002). Personal experiences establish students' personal understandings based on their life experiences (Vygotsky, 1980). For third-grade African American male students to succeed in reading to the level of excellence observed on each study campus, these students must have solid foundations in place. These foundations are built through personal experiences (see Vygotsky, 1980). 


\section{Implications}

The findings of this study have the potential to play a role in creating positive social change for the teachers of third-grade African American boys attending Title I schools in East Texas in the area of reading proficiency as well as the third-grade African American male students attending these schools. Both groups may experience a positive change. The teachers will have more instructional strategies available to teach this student group. The students will benefit from the improved instructional strategies and practices.

Educators who work with this student group can take the findings from this study and implement the strategies with this population of students to improve academic success in the area of reading. Understanding how to reach the African American male attending a Title I school provides positive change for educators. Because this population has shown a history of academic struggle in the area of reading, understanding how to plan and execute reading instruction to this group will allow for less stress on the part of the educator, leading to more time to enrich learning opportunities. In turn, these enriched learning opportunities could lead to better academic and emotional support for the student focus group followed by higher levels of reading achievement.

According to the educators in this study, through increased reading proficiency for the students, other academic areas may be affected in a positive manner. As success spreads to other academic areas, further opportunities could be available to the students. These opportunities have potential to affect the child's lifetime learning potential possibly leading to a better social and academic outcome (see Allen \& White-Smith, 2014). By improving academic outcomes, the possibility of improved professional opportunities increases.

Without the information in this study, many students could continue to struggle in reading. These students might never experience the level of reading success without the instructional strategies outlined from the study's findings. Through knowledge of these effective instructional strategies, teachers who serve this group of students are offered the opportunity to teach in a manner that has potential to reverse a history of failure and move forward to meet a new level of success in reading for these students. The data from this study have the capacity to be life altering for the teachers and students alike.

\section{Conclusion}

Educators enter classrooms every day ready to make a difference for every student they come in contact with. The subpopulation of third-grade African American boys attending Title I schools in East Texas is a student group who has not often met mastery in reading as evidenced in the state reading assessment scores (see Texas Education Agency, n.d.). With this in mind, this study was developed to investigate how a small number of schools in this region have helped this group of students meet an acceptable level of mastery in reading.

Knowing those students, from this subpopulation, not on an appropriate level by the end of third grade in the area of literacy are at a higher risk level for academic failures, provided an ignition for a quest to find a solution (see Allen \& White-Smith, 2014; Cartledge et al., 2016; Coggshall et al., 2013; J. Williams \& Portman, 2014). From the study's findings, it is recommended that educators implement CRP on their campuses and within their classrooms. Educators should be aware of students' cultures and how they best communicate and learn. Relationships were shown to play a strong role in academic achievement. When a child knows they are cared for, and cared about, they find a level of safety that allows them to open up, enter in, and learn.

Although the State of Texas requires a specific reading curriculum be taught at each grade level, the presentation of this reading curriculum proved to be the difference in the students' success on these 
campuses (Texas Education Agency, n.d.). Above all, a relationship should be built and strengthened based on mutual respect and understanding. It is the careful melding of a strong academic climate with a supportive emotional, or affective, climate that provides the greatest support for this group of students. When a student feels safe and secure, behaviors begin to change. When a student feels safe and secure, learning can begin. These students will take risks so they can experience success. Begin building strong relationships with students and half the battle is won.

\section{References}

Allen, Q., \& White-Smith, K. A. (2014). "Just as bad as prisons": The challenge of dismantling the school-to-prison pipeline through teacher and community education. Equity \& Excellence in Education, 47, 445-460. doi:10.1080/10665684.2014.958961

$\mathrm{Au}, \mathrm{K} . \mathrm{H}$. (1998). Social constructivism and the school literacy learning of students of diverse backgrounds. Journal of Literacy Research, 30, 297-319. doi:10.1080/10862969809548000

Babbie, E. (2017). The basics of social research. Boston, MA: Cengage Learning.

Benegas, M. (2014). Teachers learning together to enact culturally relevant pedagogy for English learners: A call to reclaim PLCs. MinneTESOL Journal, 30, 1-11.

Bigler, R. S., \& Wright, Y. F. (2014). Reading, writing, arithmetic, and racism? Risks and benefits to teaching children about intergroup biases. Child Development Perspectives, 8, 18-23. doi:10.1111/cdep.12057

Boon, H. J., \& Lewthwaite, B. (2015). Development of an instrument to measure a facet of quality teaching: Culturally responsive pedagogy. International Journal of Educational Research, 72, 38-58. doi:10.1016/j.ijer.2015.05.002

Butin, D. W. (2010). The education dissertation: A guide for practitioner scholars. Thousand Oaks, CA: Corwin.

Cartledge, G., Keesey, S., Bennett, J. G., Ramnath, R., \& Council III, M. R. (2016). Culturally relevant literature: What matters most to primary-age urban learners. Reading \& Writing Quarterly, 32, 399-426. doi:10.1080/10573569.2014.955225

Coggshall, J. G., Osher, D., \& Colombi, G. (2013). Enhancing educators' capacity to stop the schoolto-prison pipeline. Family Court Review, 51, 435-444. doi:10.1111/fcre.12040

Davis, E. R. (2016). Promoting and selecting culturally relevant teaching materials and pedagogy in our schools (Doctoral dissertation). Foster G. McGaw Graduate School, National Louis University, Chicago, IL.

Drevdahl, D. J. (2017). Impersonating culture: The effects of using simulated experiences to teach cultural competence. Journal of Professional Nursing, 34, 195-204. doi:10.1016/j.profnurs.2017.10.006

DuFour R., \& DuFour, R. (2012). The school leader's guide to professional learning communities at WorkTM. Bloomington, IN: Solution Tree Press.

Duggins, S., \& Acosta, M. M. (2019). Reading aloud in an era of common core: An exploratory study of the perspectives of primary teachers serving African American children in low-income communities. Journal of Early Childhood Literacy, 19, 252-278. doi:10.1177/1468798417716980

Dumas, J. M. (2017). Highly effective teachers of African American students: Personal characteristics, classroom climate, and instructional practices (Doctoral dissertation). Retrieved from ProQuest Dissertations and Theses database. (UMI No. 10263466) 
Durden, T. R., Escalante, E., \& Blitch, K. (2015). Start with us! Culturally relevant pedagogy in the preschool classroom. Early Childhood Education Journal, 43, 223-232. doi:10.1007/s10643014-0651-8

Edwards, O. W., \& Taub, G. E. (2016). The influence of specific phonemic awareness processes on the reading comprehension of African American students. Journal of Research in Childhood Education, 30, 74-84. doi:10.1080/02568543.2015.1105332

Ford, B. A., Stuart, D. H., \& Vakil, S. (2014). Culturally responsive teaching in the 21 st century inclusive classroom. Journal of the International Association of Special Education, 15, 56-62.

Fraise, N. J., \& Brooks, J. S. (2015). Toward a theory of culturally relevant leadership for schoolcommunity culture. International Journal of Multicultural Education, 17, 6-21. doi:10.18251/ijme.v17i1.983

Fries-Britt, S. (2017). It takes more than academic preparation: A nuanced look at Black male success in STEM. Journal of African American Males in Education, 8, 6-22.

Gay, G. (2013). Teaching to and through cultural diversity. Curriculum Inquiry, 43, 48-70. doi:10.1111/curi.12002

Gray, S. L. (2017). School district information technology disaster recovery planning: An explanatory case study (Doctoral dissertation). Retrieved from ProQuest Dissertations and Theses database. (UMI No. 10258058)

Jenkins, R. (2016). A case study of an African American community's perceptions of problems in mathematics education (Doctoral dissertation). Retrieved from ProQuest Dissertations and Theses database. (UMI No. 10006986)

Jones, M. G., \& Brader-Araje, L. (2002). The impact of constructivism on education: Language, discourse, and meaning. American Communication Journal, 5, 1-10.

Kelly, L. L. (2013). Hip-hop literature: The politics, poetics, and power of hip-hop in the English classroom. English Journal, 102, 51-56.

Kirsch, I., \& Lennon, M. L. (2017). PIAAC: A new design for a new era. Large-scale Assessments in Education, 5, 1-22. doi:10.1186/s40536-017-0046-6

Kurtz-Costes, B., Swinton, A. D., \& Skinner, O. D. (2014). Racial and ethnic gaps in the school performance of Latino, African American and White students. In F. T. L. Leong, L. ComasDíaz, G. C. Nagayama Hall, V. C. McLoyd, \& J. E. Trimble (Eds.), APA handbook of multicultural psychology: Theory and research (pp. 231-246). Washington, DC: American Psychological Association. doi:10.1037/14189-012

Ladson-Billings, G. (1995a). But that's just good teaching! The case for culturally relevant pedagogy. Theory Into Practice, 34, 159-165. doi:10.1080/00405849543675

Ladson-Billings, G. (1995b). Toward a theory of culturally relevant pedagogy. American Educational Research Journal, 32, 465-491. doi:10.3102/00028312032003465

Ladson-Billings, G. (2014). Culturally relevant pedagogy 2.0: a.k.a. the remix. Harvard Educational Review, 84, 74-84. doi:10.17763/haer.84.1.p2rj131485484751

Ladson-Billings, G. (2018, January 29). The significance of culturally relevant pedagogy [Webinar]. Presented at A Black Education Network. Retrieved from https://www.aben4ace.org/

Liou, D. D., \& Rotheram-Fuller, E. (2019). Where is the real reform? African American students and their school's expectations for academic performance. Urban Education, 54, 397-429. doi:10.1177/0042085915623340

Meier, T. (2015). "The brown face of hope": Reading engagement and African American boys. The Reading Teacher, 64. 335-343. doi:10.1002/trtr.1310 
Merriam, S. B., \& Tisdell, E. J. (2015). Qualitative research: A guide to design and implementation. San Francisco, CA: John Wiley \& Sons.

Newman-Brown, N. T. (2016). Increasing black student literacy proficiency using English Language Learner instructional strategies (Doctoral dissertation). Retrieved from ProQuest Dissertations and Theses database. (UMI No. 10006978)

Palincsar, A. S. (1998). Social constructivist perspectives on teaching and learning. Annual Review of Psychology, 49, 345-375. doi:10.1146/annurev.psych.49.1.345

Paris, D., \& Alim, H. S. (2014). What are we seeking to sustain through culturally sustaining pedagogy? A loving critique forward. Harvard Educational Review, 84, 85-101.

Phillippi, J., \& Lauderdale, J. (2018). A guide to field notes for qualitative research: Context and conversation. Qualitative Health Research, 28, 381-388. doi:10.1177/1049732317697102

Powell, K. C., \& Kalina, C. J. (2009). Cognitive and social constructivism: Developing tools for an effective classroom. Education, 130, 241-250.

Ratner, B. (2017). Statistical and machine-learning data mining: Techniques for better predictive modeling and analysis of big data. Boca Raton, FL: Chapman and Hall/CRC.

Ravitch, S. M., \& Carl, N. M. (2016). Qualitative research: Bridging the conceptual, theoretical, and methodological. Thousand Oaks, CA: Sage.

Rowley, S. J., Ross, L., Lozada, F. T., Williams, A., Gale, A., \& Kurtz-Costes, B. (2016). Framing Black boys: Parent, teacher, and student narratives of the academic lives of Black boys. In S.S. Horn, M.D. Ruck and L.S. Liben (Eds.), Advances in child development and behavior (pp. 303-327). Amsterdam, The Netherlands: Elsevier.

Rubin, H. J., \& Rubin, I. S. (2012). Qualitative interviewing: The art of hearing data (3rd ed.). Thousand Oaks, CA: Publications.

Snow, C. E., \& Matthews, T. J. (2016). Reading and language in the early grades. The Future of Children, 26, 57-74. doi:10.1353/foc.2016.0012

Taylor, R., \& Thomas-Gregory, A. (2015). Case study research. Nursing Standard, 29, 36-40. doi:10.77448/ns.29.41.36.e8856

Texas Education Agency. (n.d.). 2015-16 Texas academic performance reports. Retrieved from https://rptsvr1.tea.texas.gov/perfreport/tapr/2016/index.html

Tomkinson, K. (2016). Indiana reading evaluation and determination (IREAD-3) assessment and third grade retention: Findings from school administrators (Doctoral dissertation). Retrieved from ProQuest Dissertations and Theses database. (UMI No. 10141373)

Vygotsky, L. S. (1980). Mind in society: The development of higher psychological processes. Cambridge, MA: Harvard University Press.

Vygotsky, L. S. (2004). Imagination and creativity in childhood. Journal of Russian \& East European Psychology, 42, 7-97. doi:10.1080/10610405.2004.11059210

Wasserberg, M. J. (2014). Stereotype threat effects on African American children in an urban elementary school. Journal of Experimental Education, 82, 502-517. doi:10.1080/00220973.2013.876224

Webb, M., \& Thomas, R. (2015). Teachers' perceptions of educators' and students' role in closing the achievement gap. National Forum of Teacher Education Journal, 25, 1-8.

Wiggan, G., \& Watson, M. J. (2016). Teaching the whole child: The importance of culturally responsiveness, community engagement, and character development in high achieving African American students. The Urban Review, 48, 766-798. doi:10.1007/s11256-016-0377-6 
Williams, E. R. (2015). A critical conversation: Remembering culture in the teaching of the whole child. Delta Kappa Gamma Bulletin, 82, 10-13.

Williams, J., \& Portman, T. (2014). "No one ever asked me": Urban African American students' perceptions of educational resilience. Journal of Multicultural Counseling and Development, 42(1), 13-30. doi:10.1002/j.2161-1912.2014.00041.x

Williams, V. (2015). The impact of literacy intervention on academic performance of third grade atrisk students (Doctoral dissertation). Retrieved from ProQuest Dissertations and Theses database. (UMI No. 10024366)

Wright, B. L., Counsell, S. L., \& Tate, S. L. (2015). "We're many members, but one body": Fostering a healthy self-identity and agency in African American boys. YC Young Children, 70, 24-31.

Wright, B. L., \& Ford, D. Y. (2016). "This little light of mine": Creating early childhood education classroom experiences for African American boys PreK-3. Journal of African American Males in Education, 7, 5-19.

Yin, R. K. (2013a). Case study research: Design and methods. (5th ed.). Thousand Oaks, CA: Sage.

Yin, R. K. (2013b). Validity and generalization in future case study evaluations. Evaluation, 19, 321332. doi:10.1177/1356389013497081

[Appendix follows] 


\section{Appendix}

\section{Effective Reading Instruction Strategies and Practices}

\begin{tabular}{|c|c|c|c|c|}
\hline & \multicolumn{2}{|c|}{ Classroom } & Campus & Other \\
\hline $\begin{array}{l}\text { Strategies/ } \\
\text { Practices }\end{array}$ & $\begin{array}{l}\text { - Act out aspects of } \\
\text { lesson/story } \\
\text { - Anchor chart creation } \\
\text { - Chants/Raps for } \\
\text { reinforcement } \\
\text { - Choral reading } \\
\text { - Clear directives/ } \\
\text { expectations } \\
\text { - Collaboration } \\
\text { - Consistency } \\
\text { - Daily formative assessments } \\
\text { - Data folder } \\
\text { - Differentiation } \\
\text { - Discussions } \\
\text { - Elaboration by students } \\
\text { - Encourage } \\
\text { - Explain the why } \\
\text { - Facilitate learning } \\
\text { - Failure is not an option! } \\
\text { - Flexibility } \\
\text { - Fluency phrases } \\
\text { - High academic expectations } \\
\text { - Ignore behaviors not } \\
\text { - Imfecting learning } \\
\text { - Include all students } \\
\text { - Listen to students }\end{array}$ & $\begin{array}{l}\text { - Make personal connections } \\
\text { - Modeling - thinking and } \\
\text { physical } \\
\text { - Movement } \\
\text { - Mnemonics use } \\
\text { - Objectives posted } \\
\text { - Pace students } \\
\text { - Personal gratitude } \\
\text { - Personal interactions } \\
\text { - Phonics } \\
\text { - Poll students } \\
\text { - Proximity } \\
\text { - Praise } \\
\text { - Push!! } \\
\text { - Redirection } \\
\text { - Repetition } \\
\text { - Researched best practices } \\
\text { - Scaffolding } \\
\text { - Set boundaries } \\
\text { - Small group instruction } \\
\text { - Spiral objectives and concepts } \\
\text { - Strong classroom management } \\
\text { - Student engagement } \\
\text { - Student interest } \\
\text { - Student ownership }\end{array}$ & $\begin{array}{l}\text { - Collaboration } \\
\text { - Data mining } \\
\text { - Relationships } \\
\text { - Response to Intervention } \\
\text { - Strong vertical alignment } \\
\text { - Teacher/Administrator } \\
\text { accountability }\end{array}$ & $\begin{array}{l}\text { - Create DVD for home use } \\
\text { - Parent academies for parent } \\
\text { training } \\
\text { - Solicit local volunteers to work } \\
\text { with students } \\
\text { - Stick with what works } \\
\text { - Strong teachers with } \\
\text { content/standards knowledge }\end{array}$ \\
\hline
\end{tabular}


The Journal of Educational Research and Practice provides a forum for studies and dialogue that allows readers to better develop social change in the field of education and learning. Journal content may focus on educational issues of all ages and in all settings. It also presents peer-reviewed commentaries, book reviews, interviews of prominent individuals, and additional content. The objectives: We publish research and related content that examines current relevant educational issues and processes aimed at presenting readers with knowledge and showing how that knowledge can be used to impact social change in educational or learning environments. Additional content provides an opportunity for scholarly and professional dialogue regarding that content's usefulness in expanding the body of scholarly knowledge and increasing readers' effectiveness as educators. The journal also focuses on facilitating the activities of both researcher-practitioners and practitioner-researchers, providing optimal opportunities for interdisciplinary and collaborative thought through blogging and other communications. Walden University Publishing:

http://www.publishing.waldenu.edu 